\title{
More insights into the immunosuppressive potential of tumor exosomes
}

\author{
Veronica Huber ${ }^{1}$, Paola Filipazzi ${ }^{1}$, Manuela Iero ${ }^{1}$, Stefano Fais ${ }^{2}$ and \\ Licia Rivoltini*1
}

\begin{abstract}
Address: ${ }^{1}$ Unit of Immunotherapy of Human Tumors, Fondazione IRCCS Istituto Nazionale Tumori, Milan, Italy and ${ }^{2}$ Department of Drug Research and Evaluation, Anti-Tumor Drugs Section, Istituto Superiore di Sanità, Rome, Italy

Email: Veronica Huber - veronica.huber@istitutotumori.mi.it; Paola Filipazzi - paola.filipazzi@istitutotumori.mi.it;

Manuela Iero - manuela.iero@istitutotumori.mi.it; Stefano Fais - Stefano.fais@iss.it; Licia Rivoltini* - licia.rivoltini@istitutotumori.mi.it

* Corresponding author
\end{abstract}

Published: 30 October 2008

Journal of Translational Medicine 2008, 6:63 doi:10.1 186/1479-5876-6-63

Received: 24 October 2008

Accepted: 30 October 2008

This article is available from: http://www.translational-medicine.com/content/6/1/63

(c) 2008 Huber et al; licensee BioMed Central Ltd.

This is an Open Access article distributed under the terms of the Creative Commons Attribution License (http://creativecommons.org/licenses/by/2.0), which permits unrestricted use, distribution, and reproduction in any medium, provided the original work is properly cited.

We did read with great interest the recent review published by Ichim et al on the potential role of tumor exosomes as immune escape mechanism [1], and we were pleased to see that the authors shared our original idea that these organelles may represent a crucial tool of immunosuppression in cancer [2,3]. Indeed, although tumor cells are well acknowledged to affect immune functions through the release of diverse soluble factors or cellto-cell contact mediated mechanisms [4,5], the involvement of alternative pathways based on the secretion of membrane microvesicles has been so far largely unappreciated [6]. Exosomes are endosome-derived organelles of 50-100 nm size, actively secreted by virtually all cell types through an exocytosis pathway that is used under normal as well as pathological conditions [6]. Their first description can be attributed to the biochemist Rose Johnstone, who reported in her 1980s investigations about these lipid-encased particles produced as a mechanism for shedding of specific membrane functions during reticulocyte maturation [7]. Since then, these curious microvesicles lingered in obscurity, although several reports kept referring to exosomes as potential pathway utilized by different cell types to eliminate cellular material or establish intercellular cross-talk [8]. Finally in 1996 these microparticles were recognized for their central role in antigen presentation with the work of Graça Raposo and Hans Geuze of Utrecht University in the Netherlands, who reported that exosomes secreted by B cells could promote T cell cross-priming through the expression of HLA/peptide complexes [6]. Based on these and following observations about the role of exosomes in antigen presentation, the exacerbated production of these vesicles by tumor cells was initially welcomed as a process potentially involved in the induction and maintenance of tumor immunity [9]. Indeed, the expression of a large panel of tumor proteins with antigenic properties, like MelanA/Mart- 1 and gp100 in melanoma-derived exosomes, and CEA and HER2 in exosomes produced by carcinoma cells [9-11], supported the role of these organelles as cell-free source of tumor antigens for T cell priming and paved the way to clinical trials based on vaccination with tumor exosomes in patients with advanced disease [12].

However, following studies from several groups including ours have progressively suggested that these vesicles, being close replicas of the originating cancer cells, could transport not only antigenic material but also molecules responsible for the detrimental effects exerted by tumor cells on the immune system $[6,13,14]$.

As most researchers, we entered the exosome field by chance, in the course of studies on FasL as tumor immune escape mechanism in human cancer. Indeed, despite the first report on the expression of FasL by melanoma [15], we could not succeed in detecting stable membrane expression of this pro-apoptotic molecule on such tumor cells. However, by using immunocytochemistry and immunoelectron microscopy, we found that FasL was indeed detectable intracellularly, as localized in defined endocytic compartments with a clear secretory behaviour. 
Thanks to this initial observation, we discovered that human melanoma as well as colon carcinoma cells constitutively release FasL and TRAIL-expressing exosomes, which induce death by apoptosis in activated $\mathrm{T}$ cells $[10,11]$. This evidence, confirmed also by Whiteside and coworkers in head and neck cancer [16], highlights a germane role of microvesicular structures in counteracting tumor immunity by simply eliminating activated $\mathrm{T}$ cells bearing tumor-reactive TCR. This might occur even at distance (in peripheral lymphoid organs, bone marrow, peripheral blood, and biological fluids) without the need for a direct cell-to-cell contact. And given the evidence that exosome of probable tumor origin are abundantly found in plasma or pathological effusions of cancer patients $[9,11]$, it can be easily hypothesized that this pathway may contribute to the in vivo moulding of immune as well as other cancer-related host responses. More recent studies have then reported that the detrimental effect of tumor exosome on immune effector functions is not restricted to T cells but can target NK cells as well, through the skewing of IL-2 responsiveness in favour of regulatory $\mathrm{T}$ cells [17] or down-modulation of NKG2D expression [18]. Moreover, the negative influence of tumor exosomes on specific immunity goes beyond T and NK cells and may also target crucial up-stream steps for T cell crosspriming, namely dendritic cell (DC) differentiation. In fact, we have more recently observed that the presence of tumor exosomes during monocyte differentiation into DC skews the whole process toward the generation of aberrant cells expressing myeloid markers (such as CD14 and CD11b), lacking or bearing low levels of co-stimulatory molecules (like HLA-DR, CD80 and CD86) and spontaneously secreting TGF-beta $[19,20]$. These cells, which exert a strong immunosuppressive activity on $\mathrm{T}$ cell proliferation and function, highly resemble the "myeloidderived suppressor cell" subset described to accumulate with tumor progression in different murine models [21]. Interestingly enough, melanoma patients with advanced disease have high levels of these CD14+ HLA-DR neg/low TGF beta-secreting cells in their peripheral blood, and this frequency appears to be a disadvantageous factor for the development of immune responses to tumor vaccines [20]. These findings, which again were confirmed in other experimental settings [22], define a very sharp profile of tumor exosomes as efficient delivery system of immunosuppression, contributing to the maintenance of an immune tolerance state in cancer bearing hosts.

The interest on exosomes has recently spread out as these vesicles are being found involved in a wide spectrum of physiological and pathological cellular events, as alternative tools of intercellular communication and paracrine functions [23], or as pathogenic pathways in viral [24] and prion-related diseases [25]. Thanks to their peculiar lipid composition, highly enriched in ceramide [26], sphingomyelin, cholesterol and GM3 glycolipid [27], exosomes may serve as a more advantageous carrier of signal delivery favouring stable conformational conditions, increased bioactivity, improved bio-distribution and amplified target interaction of their protein content with respect to soluble molecules. In the last years, literature is indeed flourishing with examples proving the role of tumor exosomes in the transfer of growth factors and cognate receptors to homologous or heterologous target cells. For instance glioma cells can share EGFR by intercellular transfer of membrane-derived microvesicles ('oncosomes') [28], or pancreatic carcinoma can deliver exosomes overexpressing tetraspanin family members and promoting autocrine secretion of MMP and VEGF [29]. The evidence that these organelles can also shape protein synthesis through the transfer of functional mRNAs and microRNAs, as recently reported in transformed mastocytes [30], adds then a further pathway to the potential modulating properties of these peculiar organelles.

If tumor exosomes are such a powerful instrument of environmental shaping, then getting rid of them should significantly affect cancer cell ability to survive and expand in vivo. In their review, Ichim et al propose a physical approach based on the extracorporeal removal of exosomes from plasma of cancer patients, through a novel hollow-fiber cartridge (Hemopurifier ${ }^{\mathrm{TM}}$ ) designed to eliminate particles expressing heavily glycosylated surface proteins, like in case of viruses and cancer microvesicles [1]. The approach could be further implemented by the attachment of clinical grade molecules and antibodies to the cartridge resin, to allow microvesicle depletion on the basis of selected marker expression. Although interesting, feasible and potentially effective in the short-term, this strategy could only have an impact on circulating exosomes, leaving vesicles accumulating at tumor tissue level, in draining lymph nodes or in other relevant lymphoid compartments, still available for immunosuppressive functions. Obviously, physical removal would not interfere with the process of exosome secretion, and would indiscriminately eliminate vesicles from both pathological and normal cells. In alternative, we are considering to intervene on tumor exosome secretion by inhibiting upstream crucial pathways involved in the process. Although definitive information on the mechanisms regulating microvesicle release by cancer cells are presently scantly, preliminary data suggest that particular molecules, such as drugs interfering with microtubule stability (taxanes and vinca alkaloids) [M. Iero, unpublished observations] or additional microtubule-disturbing molecules like vincristine [31], can affect endosomal stability and reduce microvesicle release. Similarly, drugs targeting the activity of enzymatic efflux pumps expressed on acidic vacuoles, such as vacuolar-ATPases inhibitors, could selectively alter exosome trafficking and release in tumor cells [Iero et al., 
unpublished, [32]]. Benefits from modulation of exosome secretion could also come from qualitatively shaping protein composition of secreted microvesicles with drugs altering biological features of tumor vesicles, such in the case of curcumin, a natural polyphenol which has been shown to reduce immunosuppressive functions of breast carcinoma-secreted exosomes [33].

A more specific approach would be instead to identify the molecular mechanisms responsible for the immunosuppressive activity and the microenvironment remodelling effects of tumor exosomes [34], to selectively interfere with these pathways through specific antibodies, antisense oligonucleotides or signalling inhibitors.

Independently from the tool utilized for diminishing exosome release by tumor cells, the most challenging task of the near future is to prove that interfering with microvesicle secretion in vivo may indeed result in tumor growth arrest or slow-down thanks to the recovery of specific immunity and the interruption of paracrine/autocrine loops in tumor microenvironment. Prior to any clinical intervention, experimental studies in animal models should thus be performed to assess what is the real impact that these vesicles play in cancer progression and what is the expected benefit of shutting off their production at tumor site.

\section{Authors contributions}

VH was responsible for editorial writing, senior scientist responsible for the studies on the immunosuppressive functions of tumor exosomes. PF was responsible for editorial reviewing, scientist responsible for the studies on the induction of myeloid-derived suppressor cells by tumor exosomes. MI was responsible for editorial reviewing, scientist responsible for the studies on the modulation of exosome release by tumor cells. SF was responsible for editorial reviewing, external collaborator in the studies on the involvement of proton-pump inhibitors on exosome release. LR was responsible for editorial writing and reviewing, supervisor of the studies on tumor exosomes

\section{References}

I. Ichim TE, Zhong Z, Kaushal S, Zheng X, Ren X, Hao X, Joyce JA, Hanley HH, Riordan NH, Koropatnick J, Bogin V, Minev BR, Min WP, Tullis RH: Exosomes as a tumor immune escape mechanism: possible therapeutic implications. J Transl Med 2008, 6:37.

2. Valenti R, Huber V, lero M, Filipazzi P, Parmiani G, Rivoltini L: Tumor-released microvesicles as vehicles of immunosuppression. Cancer Res 2007, 67:2912-2915.

3. lero M, Valenti R, Huber V, Filipazzi P, Parmiani G, Fais S, Rivoltini L: Tumour-released exosomes and their implications in cancer immunity. Cell Death Differ 2008, I 5:80-88.

4. Marincola FM, Jaffee EM, Hicklin DJ, Ferrone S: Escape of human solid tumors from $\mathrm{T}$-cell recognition: molecular mechanisms and functional significance. Adv Immunol 2000, 74: I8I-273.

5. Rivoltini L, Canese P, Huber V, lero M, Pilla L, Valenti R, Fais S, Lozupone F, Casati C, Castelli C, Parmiani G: Escape strategies and reasons for failure in the interaction between tumour cells and the immune system: how can we tilt the balance towards immune-mediated cancer control? Expert Opin Biol Ther 2005, 5:463-476.

6. van Niel G, Porto-Carreiro I, Simoes S, Raposo G: Exosomes: a common pathway for a specialized function. J Biochem 2006, 140:|3-2|.

7. Johnstone RM: The Jeanne Manery-Fisher Memorial Lecture 1991. Maturation of reticulocytes: formation of exosomes as a mechanism for shedding membrane proteins. Biochem Cell Biol 1992, 70:179-190.

8. Johnstone RM: Exosomes biological significance: A concise review. Blood Cells Mol Dis 2006, 36:315-32l.

9. Andre F, Schartz NE, Movassagh M, Flament C, Pautier P, Morice P, Pomel C, Lhomme C, Escudier B, Le Chevalier T, Tursz T, Amigorena S, Raposo G, Angevin E, Zitvogel L: Malignant effusions and immunogenic tumour-derived exosomes. Lancet 2002, 360:295-305.

10. Andreola G, Rivoltini L, Castelli C, Huber V, Perego P, Deho P, Squarcina P, Accornero P, Lozupone F, Lugini L, Stringaro A, Molinari A, Arancia G, Gentile M, Parmiani G, Fais S: Induction of lymphocyte apoptosis by tumor cell secretion of FasL-bearing microvesicles. J Exp Med 2002, 195: | 303-1316.

II. Huber V, Fais S, lero M, Lugini L, Canese P, Squarcina P, Zaccheddu A, Colone M, Arancia G, Gentile M, Seregni E, Valenti R, Ballabio G, Belli $F$, Leo E, Parmiani G, Rivoltini L: Human colorectal cancer cells induce $\mathrm{T}$-cell death through release of proapoptotic microvesicles: role in immune escape. Gastroenterology 2005, I 28: $1796-1804$.

12. Chaput N, Schartz NE, Andre F, Zitvogel L: Exosomes for immunotherapy of cancer. Adv Exp Med Biol 2003, 532:215-221.

13. Taylor DD, Gerçel-Taylor C: Tumour-derived exosomes and their role in cancer-associated $\mathrm{T}$-cell signalling defects. $\mathrm{Br} J$ Cancer 2005, 92:305-3II.

14. Whiteside TL: Tumour-derived exosomes or microvesicles: another mechanism of tumour escape from the host immune system? Br J Cancer 2005, 92:209-2II.

15. Hahne M, Rimoldi D, Schröter M, Romero P, Schreier M, French LE, Schneider P, Bornand T, Fontana A, Lienard D, Cerottini J, TschopP J: Melanoma cell expression of Fas(Apo-I/CD95) ligand: implications for tumor immune escape. Science 1996, 274: I363-I366.

16. Kim JW, Wieckowski E, Taylor DD, Reichert TE, Watkins S, Whiteside TL: Fas ligand-positive membranous vesicles isolated from sera of patients with oral cancer induce apoptosis of activated T lymphocytes. Clin Cancer Res 2005, I I:1010-1020.

17. Clayton A, Mitchell JP, Court J, Mason MD, Tabi Z: Human tumorderived exosomes selectively impair lymphocyte responses to interleukin-2. Cancer Res 2007, 67:7458-7466.

18. Clayton A, Mitchell JP, Court J, Linnane S, Mason MD, Tabi Z: Human tumor-derived exosomes down-modulate NKG2D expression. J Immunol 2008, I 80:7249-7258.

19. Valenti R, Huber V, Filipazzi P, Pilla L, Sovena G, Villa A, Corbelli A, Fais S, Parmiani G, Rivoltini L: Human tumor-released microvesicles promote the differentiation of myeloid cells with transforming growth factor-beta-mediated suppressive activity on T lymphocytes. Cancer Res 2006, 66:9290-9298.

20. Filipazzi P, Valenti R, Huber V, Pilla L, Canese P, lero M, Castelli C, Mariani L, Parmiani G, Rivoltini L: Identification of a new subset of myeloid suppressor cells in peripheral blood of melanoma patients with modulation by a granulocyte-macrophage colony-stimulation factor-based antitumor vaccine. J Clin Oncol 2007, 25:2546-2553.

21. Serafini P, Borrello I, Bronte V: Myeloid suppressor cells in cancer: recruitment, phenotype, properties, and mechanisms of immune suppression. Semin Cancer Biol 2006, 1 6:53-65.

22. Yu S, Liu C, Su K, Wang J, Liu Y, Zhang L, Li C, Cong Y, Kimberly R, Grizzle WE, Falkson C, Zhang HG: Tumor exosomes inhibit differentiation of bone marrow dendritic cells. J Immunol 2007 , I 78:6867-6875.

23. Théry C, Zitvogel L, Amigorena S: Exosomes: composition, biogenesis and function. Nat Rev Immunol 2002, 2:569-579.

24. Gould SJ, Booth AM, Hildreth JE: The Trojan exosome hypothesis. Proc Natl Acad Sci USA 2003, I 00: 10592-10597.

25. Fevrier B, Vilette D, Archer F, Loew D, Faigle W, Vidal M, Laude H, Raposo G: Cells release prions in association with exosomes. Proc Natl Acad Sci USA 2004:9683-9688. 
26. Trajkovic K, Hsu C, Chiantia S, Rajendran L, Wenzel D, Wieland F, Schwille $P$, Brügger $B$, Simons $M$ : Ceramide triggers budding of exosome vesicles into multivesicular endosomes. Science 2008, 3 | 9: | 244-1247.

27. Subra C, Laulagnier K, Perret B, Record M: Exosome lipidomics unravels lipid sorting at the level of multivesicular bodies. Biochimie 2007, 89:205-2। 2 .

28. Al-Nedawi K, Meehan B, Micallef J, Lhotak V, May L, Guha A, Rak J: Intercellular transfer of the oncogenic receptor EGFRvIII by microvesicles derived from tumour cells. Nat Cell Biol 2008, 10:619-624.

29. Gesierich S, Berezovskiy I, Ryschich E, Zöller M: Systemic induction of the angiogenesis switch by the tetraspanin D6.IA/ CO-029. Cancer Res 2006, 66:7083-7094.

30. Valadi H, Ekström K, Bossios A, Sjöstrand M, Lee J], Lötvall JO: Exosome-mediated transfer of mRNAs and microRNAs is a novel mechanism of genetic exchange between cells. Nature Cell Biol 2007, 9:654-659.

31. Groth-Pedersen L, Ostenfeld MS, Høyer-Hansen M, Nylandsted J, Jättelä M: Vincristine induces dramatic lysosomal changes and sensitizes cancer cells to lysosome-destabilizing siramesine. Cancer Res 2007, 67:2217-2225.

32. Luciani F, Spada M, De Milito A, Molinari A, Rivoltini L, Montinaro A, Marra M, Lugini L, Logozzi M, Lozupone F, Federici C, lessi E, Parmiani $\mathrm{G}$, Arancia G, Belardelli F, Fais S: Effect of proton pump inhibitor pretreatment on resistance of solid tumors to cytotoxic drugs. J Natl Cancer Inst 2004, 96(22): I702-17।3.

33. Hang HG, Kim H, Liu C, Yu S, Wang J, Grizzle WE, Kimberly RP, Barnes S: Curcumin reverses breast tumor exosomes mediated immune suppression of NK cell tumor cytotoxicity. Biochim Biophys Acta 2007, I 773: I I I6- I I 23.

34. Cheng P, Corzo CA, Luetteke N, Yu B, Nagaraj S, Bui MM, Ortiz M, Nacken W, Sorg C, Vogl T, Roth J, Gabrilovich DI: Inhibition of dendritic cell differentiation and accumulation of myeloidderived suppressor cells in cancer is regulated by SIO0A9 protein. J Exp Med 2008, 205:2235-2249.

Publish with Bio Med Central and every scientist can read your work free of charge

"BioMed Central will be the most significant development for disseminating the results of biomedical research in our lifetime. "

Sir Paul Nurse, Cancer Research UK

Your research papers will be:

- available free of charge to the entire biomedical community

- peer reviewed and published immediately upon acceptance

- cited in PubMed and archived on PubMed Central

- yours - you keep the copyright
BioMedcentral 